\title{
MAKING HISTORY IN AFRICA: DAVID HENIGE AND THE QUEST FOR METHOD IN AFRICAN HISTORY
}

\author{
MiChEL R. DOORTMONT \\ UNIVERSITY OF GRONINGEN
}

I

My own history with David Henige goes back to 1985, when I had just finished a master's degree in African studies at the Centre of West African Studies in Birmingham, England, and was looking for a place and a supervisor for a planned doctoral dissertation involving a historiographical study of Nigeria. One of my supervisors, Tom McCaskie, suggested getting in touch with Henige, to see if he could assist me. The reply was elaborate and positive, which I appreciated much. Circumstances for graduate students at the time being quite different from the present, and funding systems for study abroad still in their infancy, the plan came to nothing. The connection with Henige and his work was there to stay, however.

This article is an effort to give a reflection on David Henige's career and his impact on the discipline of history in Africa, through his work as editor of History in Africa. The scope of the reflection is limited, as we concentrate on David's own contributions, rather than setting him and his work in a comparative framework. When David Henige started History in Africa in 1974, it was yet another scholarly journal on Africa, in an ever-growing series, counting already more than two hundred titles, as Henige pointed out himself.' And indeed, in such circumstances, a new journal needs 'to justify itself to the audience it addresses. ${ }^{2}$

Before we look closer at the justification Henige provided back in 1974, let us first take a step back and look at the historical and historiographical

\footnotetext{
'David Henige, "On Method: An Apologia and a Plea," History in Africa 1 (1974), 1.

${ }^{2}$ Henige, "On Method," 1.
}

History in Africa 38 (2011), 7-20 
context in which the journal appeared. Here two perspectives are possible. The first is the perspective of the growth of African history as a discipline in general in the two decades before History in Africa was born. The period from the mid-1950s to the mid-1970s saw an astonishing number of changes taking place on the African continent. First of all, there was the road to independence for a fair number of African countries in West Africa, starting with Ghana in 1957, and followed by Nigeria and the other British West African colonies, and the French colonies. Central and East Africa followed suit, and, by the mid-1960s, most of the African continent had gained its independence. In this process, the study of history became an important instrument for state building and national and cultural (self-) identification. As such, the trade of African history modernized quickly, with academic institutions inside and outside Africa devoting themselves to the subject, and even setting up specialized institutes for African studies. In this context of academic activity, a natural outlet was the forming of a number of journals. What was new, however, was that African academic institutions for the first time started to publish scholarly journals on history, often focusing on the national and regional histories of the countries that spawned them. In effect this meant that the debate on what African history was and should be, was now entered by African historians on the African continent, releasing the field from its colonial shackles, so to speak. The high point of this development fell in the mid to late 1960 s, and coincided with the first set of political and economic crises in the continent. ${ }^{3}$ Apart from the regional perspective several journals adopted an ideological or political perspective on history and historiography, in line with more general political developments of the period.

As Henige pointed out quite rightly in the first issue of History in Africa, not all aspects of African history were covered adequately in the available journals. He then continued to state that:

Because this study [African history] is so recent the emphasis, both in research itself and in the format of the journals, has been on the collection, use, and presentation of data. It cannot be denied that these procedures have been and will remain the chief concerns of historical enquiry, but they are not the only ones. The value of data obviously depends, first, on its validity, and, second, on its use. The assessment of these aspects in turn depends on the close and continued scrutiny of sources as well as on the quality of historical thought. ${ }^{4}$

${ }^{3}$ Frederick Cooper, Africa since 1940: The Past of the Present (Cambridge, 2002), chapter 3.

${ }^{4}$ Henige, "On Method," 1. 
The opening article of the journal, Henige carefully presented a vision and a program. The vision is clear-cut, and in hindsight perhaps a bit unsurprising. The program was ambitious. The idea was that the journal would address: (1) archival research, (2) text criticism, (3) historiography and (4) comparative research. ${ }^{5}$ In his own words:

History in Africa will include articles on source criticism and evaluation and the nature of history and historical thought, surveys of the historiography of themes and events, archival and bibliographic reports, review essays of methodological works, and studies of historical problems which are comparative in focus or approach. ${ }^{6}$

The remainder of the introductory article is an exposé of comparative historiography, and focuses predominantly on historiographical traditions that can be of use for the study of African history, but seem to be overlooked by many historians. In effect, Henige's overall plan for History in Africa hinged on the idea that African history was both vastly different from, and exactly the same as other types of history. It became an adagio that Henige adhered to throughout all his work. We will return to the program later in this article.

It can safely be said that History in Africa from the start proved to fill a niche in the large set of already existing African studies journals. It is also safe to say that it kept that niche throughout its existence. The journal started out with a first volume of 120 pages, which appeared in April 1975, and grew gradually into an annual volume of up to and even over 500 pages. Authors are keen to submit their work to the journal, knowing the journal offers a platform and an audience for often quite particular topics. For many years it was rather difficult to assess the reception of materials, other than through general citation indexes, which are often not geared towards the fair measurement of niche publications. In recent years, the Africa Studies Association brought its two main publications under the umbrellas of the digital repositories JSTOR and Project Muse. In addition to citations, it is now possible to measure the number of hits for the full series. For 2010 the number of downloaded articles through Project Muse alone stood at 4,612.?

\footnotetext{
${ }^{5}$ Henige, "On Method," 1; David Henige, "It Is a Job I Would Like," History in Africa 36 (2009), 1-3.

${ }^{6}$ Henige, "On Method," 1.

${ }^{7}$ Info from Project Muse through ASA, covering downloads from volumes 32 (2005) to 37 (2010). The editors of $H A$ will in the future monitor the figures, and analyze them where possible, to get a better insight into the interest of the readership. Other journals on African history are already doing this.
} 
During his career, David Henige has stressed many times that he was not just an African historian. And indeed, when we look at Henige's list of achievements, he is much more. Nevertheless, he is best known for his contributions to African history both through History in Africa and a host of publications in book and article form. Let us first have a look at Henige's career here and see how he could best be qualified.

Henige did his first degree in the University of Toledo, Ohio, where he graduated in history in 1959. After an intermezzo, he pursued this course with an MA in the same university, which set him up as an aspiring researcher in African history, which led to a PhD in that subject at the University of Wisconsin in $1973 .^{8}$ Wisconsin was to remain his professional home, except for a short, but not unimportant sojourn as lecturer at the Centre of West African Studies in Birmingham (Great Britain).

At the time, the University of Wisconsin at Madison and Northwestern University in Chicago had established themselves as hotbeds for the study of African history. The former, with Belgian historian Jan Vansina at the helm, was in particular delving into the history of Central Africa and the use of oral traditions as a viable source for historical study. The program at Northwestern, with Welshman Ivor Wilks in charge, focused on West African history, with a special interest in the Gold Coast and Ashanti and issues of pre-colonial state formation. The two programs, set up in the 1960 s, heralded the coming of age of African history in American universities, and its establishment as an academic subject separate from AfricanAmerican history. Vansina and Wilks were trendsetters in the field in the Anglophone world, together with John Fage (Centre of West African Studies, University of Birmingham) and Roland Oliver (SOAS, University of London) in Britain.

In 1961, Jan Vansina published his doctoral dissertation on oral tradition in French, followed by an English edition in 1965 as Oral Tradition: A Study in Historical Methodology. ${ }^{9}$ The book was widely received and had an immediate impact on the study of African history. At the time Vansina developed his thesis on the use of oral traditions as an historical source, the

\footnotetext{
${ }^{8}$ Information on career and publications was derived from a resume kindly provided by David Henige.

${ }^{9}$ Jan Vansina, Oral Tradition: A Study in Historical Methodology (London, 1965).
} 
need for alternative approaches to the study of African history had become compelling. ${ }^{10}$ Already in the mid-1950s, the Nigerian historian Kenneth Dike had used oral traditions and oral history for his doctoral study on nineteenth-century trade and politics in the Niger Delta. ${ }^{11}$ This study still stood firmly in the tradition of English liberal history, however, and relied as much on documentary sources as it did on oral materials, if not more. Vansina provided the first proper methodology for the use of oral tradition as historical source, especially for societies severely lacking in written documentary sources, which was his own field of expertise. At the time there was still a debate going on about the value of oral tradition as a source for serious historical research, in spite of the pioneering work of Dike and others. ${ }^{12}$ Vansina's work effectively ended this debate.

By the early 1970s, oral tradition had become part and parcel of the research methods for African history, and the debate on the subject had shifted to questions about quality and usability of oral traditions in specific cases, as well as the interaction between written and oral sources. Henige developed his own doctoral project on the crossroads in the debate, and took up one specific challenge in the practical discussion about the usability of oral traditions as a source: chronology. Already in 1966, the School of Oriental and African Studies had organized a conference on African chronology, which resulted in a special issue of the Journal of African History. ${ }^{13}$

The conclusion of the conference was rather disappointing, as co-organizer D.H. Jones pointed out in his introductory article, "the general picture [being that] of a situation where almost everything remains to be done or done again."14 Henige tackled this problem in his doctoral research from a perspective that broke open the discipline of African history. Although academically still young, the field was already showing a tendency - willingly or unwillingly, wittingly or unwittingly - to become too inward-looking for its own (methodological) good. In his first publication on the subject, Henige argued forcefully that what was lacking in the conference and the

\footnotetext{
${ }^{10}$ Toyin Falola, and Michel R. Doortmont, "[Review of] Jan Vansina, Oral Tradition as History" African Economic History 14 (1985), 237-39.

${ }^{11}$ Kenneth O. Dike, Trade and Politics in the Niger Delta, 1830-1890: An Introduction to the Economic and Political History of Nigeria (Oxford, 1956).

${ }^{12}$ Falola, and Doortmont, "Review," 237.

${ }^{13}$ Problems of African Chronology, special issue of Journal of African History 11 (1970), 161-268; David Henige, "Oral Tradition and Chronology," Journal of African History 12 (1971), 371-89, 371.

${ }^{14}$ D.H. Jones, 'Problems of African Chronology," Journal of African History 11 (1970), $161-76,162$.
} 
resulting publication was the ability to develop a more comparative perspective. One relied too heavily on African data and had no eye for data and information from other regions of the world. In his own paper, he tried to amend this by arguing for a strong empirical and analytical comparative approach. ${ }^{15}$ It was to become one of Henige's professional preoccupations.

Henige's doctoral dissertation was published three years later under the title The Chronology of Oral Tradition: Quest for a Chimera. ${ }^{16}$ The subtitle - originally the main title of the dissertation - is a strong indication of the author's thought processes and the way in which his views on the subject developed over time. Indeed, the conclusion Henige draws in his book is unequivocal: "traditional evidence generally has been found wanting, at least for periods of more than a century before the initial transcription of the tradition." 17 It led the young reviewer Robin Law to suggest that "Dr. Henige himself appears somewhat depressed by his conclusions." For Law, however, there was no reason to be depressed: "His liquidation of much inadequately grounded historical reconstruction is invigorating rather than daunting." 18 Law followed on with what was to become the general opinion about the book, namely that Henige set the agenda for the methodologies of research in African history on two fronts: (1) how to deal with problems surrounding traditions "encountered not in oral form, but incorporated into written history," and (2) "the extensive use of comparative material from outside Africa." 19 In both respects Henige proved himself to be a successful iconoclast, insofar that he laid bare an important deficiency in Vansina's work in the first case, and made short shrift with any tendency towards selfindulgence and "mumbo-jumbo about the 'unique' character of African history" in the second. ${ }^{20}$

Anthropologist Elizabeth Tonkin emphasized the implied problem of "patterns of thinking employed in remembrance, and the patterns of literacy on them," who went on to explore these elements - among others - to be published in book form years later. ${ }^{21}$ Historian Andrew Roberts was gener-

\footnotetext{
${ }^{15}$ Henige, "Oral Tradition and Chronology," 371.

${ }^{16}$ David Henige, The Chronology of Oral Tradition: Quest for a Chimera (Oxford, 1974).

${ }^{17}$ Henige, The Chronology, 190.

${ }^{18}$ R.C.C. L[aw], "The Chronology of Oral Tradition," Journal of African History 17 (1976), 308.

${ }^{19}$ Law, "The Chronology," 308.

${ }^{20} \mathrm{Law}$, "The Chronology," 308.

${ }^{21}$ Elizabeth Tonkin, "[Review of] David P. Henige, The Chronology of Oral Tradition: Quest for a Chimera," Social History 1 (1976), 399; Elizabeth Tonkin, Narrating our Pasts: The Social Construction of Oral History (Cambridge, 1995).
} 
ally enthusiastic, but regretted that Henige had not looked "further into the growth of both 'linear' history-writing and of a critical approach capable of reconciling such history with the testimony of 'non-linear' historians." 22 It is a valid comment, but also rather gratuitous. Incorporating this problem in the original study, would only have been possible by setting up a second, parallel, research project, which was not within the scope of doctoral research. Other reviewers were also generally enthusiastic about the book, and confirmed its timeliness and perspective in relationship to the development of African history as a discipline.

For his study, Henige did fieldwork in Ghana, where he looked into kingship and kinglists in the Central Region, among the Fante and in the city-state of Elmina. Part of the material he gathered here was used in his book in the form of case studies. More importantly, however, Henige published two articles on the basis of the Ghanaian material which addressed the problem of "feedback" in oral tradition. One article compared four examples from the Fante area of Ghana. The other discussed kingship in the city-state of Elmina, more especially the phenomenon of published kinglists. Although Henige covered "feedback" in his book, the extracted articles are in many ways far more evocative, and have become classics in their own right. It is safe to say that with them, Henige coined the term "feedback" for African historiography. ${ }^{23}$ Other articles on Ghanaian history from the 1970 s and 1980s, often looking at more general empirical problems and events, are also still important to date.

From his early articles and his book, it is clear that Henige was a man with a mission. Strict on himself, as with others, this regularly led to lively debate in the journals, and occasionally to some controversy. In effect this was part of what Henige had in mind when he started History in Africa.

Henige's publishing record is both varied and prolific: from 1971 onwards he published 15 books, 189 articles, and 169 book reviews. And this is the record to date, as we are still counting. Henige's academic interests are varied. Most colleagues in the field will know him as an African historian and African studies specialist. Professionally, he worked much of

${ }^{22}$ Andrew D. Roberts, "[Review of] David P. Henige, The Chronology of Oral Tradition: Quest for a Chimera," Bulletin of the School of Oriental and African Studies 38 (1975), 692-93.

${ }^{23}$ David Henige, "The Problem of Feedback in Oral Tradition: Four Examples from the Fante Coastlands," Journal of African History 14 (1974), 223-35; David Henige, "Kingship in Elmina before 1869: A Study in 'Feedback' and the Traditional Idealization of the Past," Cahiers d'Etudes Africaines 55 (1974), 499-520. 
his career as African Studies Bibliographer at the University of Wisconsin Library, which highlights his "Africanist identity." Before going into that identity a little bit deeper, it is necessary to mention some of his other interests and identities. Reading Henige's publication list shows him to be a very versatile and multi-talented scholar. He published on bibliography and library sciences, on publishing, on Columbus in American history, on American-Indian history, on ancient and medieval history, on genealogy, and many more topics, in over fifty peer-reviewed scholarly journals. It is a record to be truly proud of. Central to all of Henige's academic activities is the quest for method - be it in the field of bibliography, the discovery and analysis of sources, or the study of comparative history.

Back to Henige "the Africanist." It seems fair to say that David Henige is one of the leading African historians of his generation. And it is noteworthy that he in part laid claim to that position through several publications that emanated from his core interest in African history, but addressed far more general problems. In the field of historiography and the interpretation of source materials his position as a theoretician is unique. As already indicated, he is the man who gave us important insights into the character and usability of oral traditions through his studies on chronology in orally transmitted histories and traditions, and who so forcefully introduced the concept of "feedback," in which elements emanating from literate discourse enter into, and become an integral part of, oral traditions. With The Chronology of Oral Tradition Henige set numerous standards for the study of (African) history through oral traditions, building on and at the same time crystallizing a debate that had been going on for well over a decade. His 1982 book, Oral Historiography, is a small, but very valuable review of the state of research of that moment, and to this day provides a working model for the use of oral sources in a traditional - written - historiographical context. ${ }^{24}$ It is a reinforcement of the position Henige claimed with his first book, and also of his position as a theoretical historian.

\section{III}

And then there is History in Africa. As befits a serious editor, Henige limited his own contributions to the Journal. For his theoretical and methodological articles, he often found (and finds) alternative journals to publish his

${ }^{24}$ David Henige, Oral Historiography (London, 1982). 
work. It confirms his status in the field. Nevertheless, Henige's contribution to the journal remains extensive, both in terms of the number of articles and the quality of the work.

Henige's contribution to the debate on "method" as such in his own journal is relatively limited, with a mere three contributions. In total, during his thirty-six years as editor, he published twenty-six articles, including three obituaries (for the iconic African historians Paul Hair, John Fage, and Philip Curtin). In terms of subject, the articles can be roughly divided into five categories that correspond to the original ones: text criticism (including sources/evidence), historiography, archival reports (including collections and bibliographies), comparative analysis (including perspective), and - last but not least - method/methodology. Henige was most active in the period 2000-2009, when he published eleven articles, against five in the 1970s, six in the $1980 \mathrm{~s}$, and four in the $1990 \mathrm{~s} .{ }^{25}$

The three articles on method and methodology are short, but stand out in this collection, because they expressly present the views of the editor on the character of the journal and its position in the field of African history. The first one presented a program, as we have already seen. ${ }^{26} \mathrm{~A}$ second article, "Of Illegal Procedure and Other Impediments to Progress," published in 1995 , is a comment on four instances in which scholarly journals declined to accept critiques of articles that had previously appeared in them. ${ }^{27} \mathrm{He}$ stresses the importance of critiques and emphasizes that in "his" journal declining on other grounds than inherent quality will not occur. The third article, "It Is a Job I Would Like," appeared at the end of Henige's term as editor and in it he looks back at that period, the original goals set, and in how far they have been achieved. ${ }^{28}$

On looking back, Henige reiterates the goals set and names them as archival reports, text criticism, historiography, and comparative studies. The topics covered by Henige himself, indicated above, and, as we shall see, the breadth of the topics addressed by other authors, cannot be categorized so strictly. In this respect the discipline of history tends to elude categorization, even - or perhaps especially - when it comes to method. What is clear from the publication list is that the field itself called for certain priorities in the

\footnotetext{
${ }^{25}$ A full overview of Henige's contributions to History in Africa can be found in the appendix to this article.

${ }^{26}$ Henige, "On Method."

${ }^{27}$ David Henige, "Of Illegal Procedure and Other Impediments to Progress," History in Africa 22 (1995), 1-3.

${ }^{28}$ David Henige, "It Is a Job I Would Like," History in Africa 36 (2009), 1-3.
} 
debate. A striking one is what can be called the category of "perspective," which links in closely to Henige's category of comparative study, but also has standing in its own right. In relationship to comparative study - looking outside the field of African history to strengthen methodology and solve historiographical problems - "perspective" offers an analytical window on such diverse problems as Africanist versus African history and the advantages and pitfalls of mono-disciplinary and multi-disciplinary studies, how to deal with questions about the quality and availability of sources, and reconsiderations of the politics and histrionics of the debate on slavery and the slave-trade.

Henige himself contributes three articles in this category, which are also solid efforts to provide a comparative approach, and analyzes the role of European historians in the transformation of Maori oral traditions and mythology into factual history. ${ }^{29}$ In "Twixt the Cup and the Lip;" he addresses the then current discussion on Margaret Mead's work in Samoa, with particular attention to the way in which her field notes were translated, or rather transformed, into publications. ${ }^{30}$ The third article deals with what Henige calls the ergonomics of African history. ${ }^{31}$ Here he makes a comparison between processes of hypothesizing and evidence collection in the case of Ötzi, the 5,000 year old man found in the Alps between Italy and Austria in 1991, and the long-standing debate on the Bantu dispersal across Africa among African historians. All are innovative approaches to the field, jogging the minds of fellow researchers by showing alternative and parallel roads to the solution of specific problems in African history. As such these articles also have a teaching quality about them.

It would go too far to discuss all the contributions. Suffice it here to say that Henige contributed in all the categories he identified in 1974, thereby leading the way for the multitude of authors that contributed to the journal. A rough-and-ready inventory of thirty-six volumes of History in Africa shows that most authors followed Henige's lead in terms of the goals set, while at the same time bringing their own perspectives and expertise to the field of method. Specifically notable in this respect are the reports on archival sources and the analyses of source usage (both oral and written). Another element of note is the truly continental character of the journal,

\footnotetext{
${ }^{29}$ David Henige, "A Snare and a Delusion," History in Africa 5 (1978), 43-61.

${ }^{30}$ David Henige, "'Twixt the Cup and the Lip:' Field Notes on the Way to Print," History in Africa 25 (1998), 119-31.

${ }^{31}$ David Henige, "Double, Double, Toil, and Trouble: The Ergonomics of African History," History in Africa 34 (2007), 103-20.
} 
with articles in all categories from all parts of Africa. Here Henige's hand as the editor is visible, more than as an author. In terms of the quality of the articles published, we can say that an above-average quality level was maintained throughout, with some immature articles, and quite a number of very good ones. Overall, History in Africa managed to link into important debates in an opportune and timely manner, adding to them from a perspective that few other journals could offer, and thus consistently providing an academic forum.

\section{IV}

At the end of this review it is apt to quote Henige's own words at the end of the introductory article in which he presented his program for the journal:

History in Africa hopes in time to become very broadly comparative and to encourage useful colloquy among the various discrete units of the discipline. In so doing it hopes to make a useful contribution to African historiography. ${ }^{32}$

In his summing-up-article published at the end of his term as editor, "It Is a Job I Would Like," Henige repeats the original goals set, and questions in how far they have been achieved. From the vantage point of semi-independent hindsight we can say that Henige succeeded in his mission. Obviously, the simple fact that the journal is nearing its fortieth anniversary is proof of its continued viability. As far as the original goals are concerned, the great variety in themes and subjects dealt with in the journal bears out that achievement too. Henige himself had his doubts as far as comparative history is concerned. It may be that ambitions clash with the reality of divided historical sub-disciplines here. The simple fact that the journal is called History in Africa naturally will not appeal to non-African historians who wish to publish their thoughts on comparative issues across regions. With changing attitudes towards the position of regional studies as academic discipline in recent years, it may now be a better moment for cross-regional comparison than before. In terms of cross-disciplinary comparison, the journal certainly succeeded. [The author might add that] Henige influenced other disciplines besides history, and African history: anthropologists, geographers, and political scientists are among the contributors to History in Africa.

${ }^{32}$ Henige, "On Method," 7. 
In conclusion we can say that the journal, so energetically set up and guided by David Henige, is proving its continued right of existence. In 2009 Henige still had to write that he was unsure how the journal would be continued after his retirement. Currently, a new editorial team has taken over, and it should be telling that a four-person team had to take over the work David did on his own for forty years.

\section{Appendix}

The following is a list of Henige's contributions to History in Africa during his term as editor (1974-2009).

"On Method: An Apologia and a Plea," History in Africa 1 (1974), 1-7.

(with Marion Johnson) "Agaja and the Slave Trade: Another Look at the Evidence," History in Africa 3 (1976), 57-67.

"A Snare and a Delusion (Or, Danger, Europeans at Work)," History in Africa 5 (1978), 43-61.

“'Bibliotheca Missionum:' A Case of Benign Neglect," History in Africa 5 (1978), 337-44.

"Some Important Collections of Catholic Missionary Journals in North America," History in Africa 6 (1979), 345-48.

"Taking Arms against a Sea of Scholarship: Serial Bibliographies and Indexes of Interest to African Historians," History in Africa 10 (1983), 109-49.

"Arms Proliferation: A Few More Serial Bibliographies of Interest to Africanist Historians," History in Africa 11 (1984), 399-402.

"Yet More Serial Bibliographies," History in Africa 12 (1985), 357-62.

"Putting the Horse Back before the Cart: Recent Encouraging Signs," History in Africa 13 (1986), 177-94.

"In Quest of Error's Sly Imprimatur: The Concept of 'Authorial Intent' in Modern Textual Criticism," History in Africa 14 (1987), 87-112.

"In the Wake of 'In the Wake of Columbus:' Why the Polemic over Columbus' First Landfall Is of Interest to Africanist Historians," History in Africa 14 (1987), 349-57.

(with James T. Sabin) "Are Bibliographers like Shortstops? Gresham's Law and Africana Bibliography," History in Africa 17 (1990), 157-69.

"Of Illegal Procedure and Other Impediments to Progress," History in Africa 22 (1995), 1-3. 
"Barbed-Wire Bonnat? The Case of the Clueless Text," History in Africa 23 (1996), 439-51.

"'Twixt the Cup and the Lip:' Field Notes on the Way to Print," History in Africa 25 (1998), 119-31.

"Being Fair to the Hounds: The Function and Practice of Annotation," History in Africa 28 (2001), 95-127.

"One-Eyed Men in the Kingdom of the Blind," History in Africa 28 (2001), 395-404.

(with Adam Jones, Robin Law, Bruce Mouser, Konrad Tuchscherer, and Selena Winsnes) "P.E.H. Hair, 1926-2001," History in Africa 29 (2002), $1-13$.

“'Being Fair to the Hounds:' The Function and Practice of Annotation, II," History in Africa 29 (2002), 63-88.

(with Paulo F. de Moraes Farias, David Henige, Adam Jones, Tom C. McCaskie, and Jan Vansina) "J.D. Fage 1921-2002," History in Africa 30 (2003), 1-9.

"Survival of the Fittest? Darwinian Adaptation and the Transmission of Information," History in Africa 30 (2003), 157-77.

"Inscriptions Are Texts Too," History in Africa 32 (2005), 185-97.

"Double, Double, Toil, and Trouble: The Ergonomics of African," History in Africa 34 (2007), 103-20.

"It Is a Job I Would Like," History in Africa 36 (2009), 1-3.

(with Joe Corry, Paul E. Lovejoy, and Patrick Manning) "Philip D. Curtin (1922-2009)," History in Africa 36 (2009), 5-15.

"Impossible to Disprove Yet Impossible to Believe: The Unforgiving Epistemology of Deep-Time Oral Tradition," History in Africa 36 (2009), 127-234.

\section{References}

Cooper, Frederick, Africa since 1940: The Past of the Present (Cambridge, 2002).

Dike, Kenneth O., Trade and Politics in the Niger Delta, 1830-1890: An Introduction to the Economic and Political History of Nigeria (Oxford, 1956).

Falola, Toyin, and Michel R. Doortmont, "[Review of] Oral Tradition as History by Jan Vansina," African Economic History 14 (1985), 237-39.

Henige, David [P.], "Oral Tradition and Chronology," Journal of African History 12 (1971), 371-89.

-, The Chronology of Oral Tradition: Quest for a Chimera (Oxford, 1974). 
-, "Kingship in Elmina before 1869: A Study in 'Feedback' and the Traditional Idealization of the Past," Cahiers d'Etudes Africaines 55 (1974), 499-520.

- , "On Method: An Apologia and a Plea," History in Africa 1 (1974), 1-7.

-, "The Problem of Feedback in Oral Tradition: Four Examples from the Fante Coastlands," Journal of African History 14 (1974), 223-35.

-, "A Snare and a Delusion," History in Africa 5 (1978), 43-61.

-, Oral Historiography (London, 1982).

-, "Of Illegal Procedure and Other Impediments to Progress," History in Africa 22 (1995), 1-3.

- , “'Twixt the Cup and the Lip:' Field Notes on the Way to Print," History in Africa 25 (1998), 119-31.

-, "Double, Double, Toil, and Trouble: The Ergonomics of African History," History in Africa 34 (2007), 103-20.

—, "It Is a Job I Would Like," History in Africa 36 (2009), 1-3.

Jones, D.H., 'Problems of African Chronology," Journal of African History 11 (1970), 161-76.

L[aw], R.C.C., "The Chronology of Oral Tradition," Journal of African History 17 (1976), 308.

Roberts, Andrew D., "[Review of] David P. Henige, The Chronology of Oral Tradition: Quest for a Chimera," Bulletin of the School of Oriental and African Studies 38 (1975), 692-93.

Tonkin, Elizabeth, "[Review of] David P. Henige, The Chronology of Oral Tradition: Quest for a Chimera," Social History 1 (1976), 399.

-, Narrating our Pasts: The Social Construction of Oral History (Cambridge, 1995).

Vansina, Jan, Oral Tradition: A Study in Historical Methodology (London, 1965). 